\title{
Philosophical Approaches to Qualitative Research
}

Julia Pryce

jpryce@luc.edu

Renée Spencer

Jill Walsh

Follow this and additional works at: https://ecommons.luc.edu/socialwork_facpubs

Part of the Social Work Commons

\section{Recommended Citation}

Pryce, Julia; Spencer, Renée; and Walsh, Jill. Philosophical Approaches to Qualitative Research. The Oxford Handbook of Qualitative Research Methods, , : 81-98, 2014. Retrieved from Loyola eCommons, Social Work: School of Social Work Faculty Publications and Other Works, http://dx.doi.org/10.1093/ oxfordhb/9780199811755.001.0001

This Book Chapter is brought to you for free and open access by the Faculty Publications and Other Works by Department at Loyola eCommons. It has been accepted for inclusion in Social Work: School of Social Work Faculty Publications and Other Works by an authorized administrator of Loyola eCommons. For more information, please contactecommons@luc.edu. (c) (i) $\Theta$

This work is licensed under a Creative Commons Attribution-Noncommercial-No Derivative Works 3.0 License. (c) Oxford University Press, 2014. 


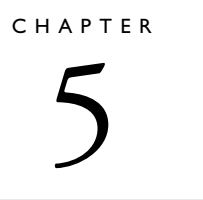

\title{
Philosophical Approaches to Qualitative Research
}

Renée Spencer, Julia M. Pryce, and Jill Walsh

\begin{abstract}
This chapter reviews some of the major overarching philosophical approaches to qualitative inquiry and includes some historical background for each. Taking a "big picture" view, the chapter discusses post-positivism, constructivism, critical theory, feminism, and queer theory and offers a brief history of these approaches; considers the ontological, epistemological, and axiological assumptions on which they rest; and details some of their distinguishing features. In the last section, attention is turned to the future, identifying three overarching, interrelated, and contested issues with which the field is being confronted and will be compelled to address as it moves forward: retaining the rich diversity that has defined the field, the articulation of recognizable standards for qualitative research, and the commensurability of differing approaches.
\end{abstract}

Key Words: Philosophical approaches, post-positivism, social constructivism, phenomenology, critical theory, rigor

Much ink has been spilled in what have been called the "paradigm wars," or battles within psychology and related disciples about how we knowand who judges - what is real. Efforts to establish the legitimacy of qualitative research have often taken the form of vociferous arguments for the merits of qualitative approaches, typically cast in terms of the contrasts between these and the more widely accepted quantitative approaches to knowledge production. More recently, even as the push toward evidence-based practice gains momentum and predictably lists the field toward greater uniformity in acceptable approaches to establishing what can be deemed credible evidence, qualitative approaches have continued to strengthen in presence and broaden in reach. Once a seeming fledging movement, despite its long but sometimes forgotten history (Wertz et al., 2011), qualitative research in psychology appears to have come of age. This maturity is reflected in the wide variety of philosophical approaches to qualitative research that have now firmly taken root.

In this chapter, we review some of the major overarching philosophical approaches to qualitative inquiry and include some historical background for each. Here, we offer a "big picture" view and leave it to other chapters in this section (on interpretive, critical, feminist, and indigenous approaches) to take a more fine-grained look at some of the particular fields of thought within these. Described by Denzin and Lincoln (2013) as "a field of inquiry in its own right" (p. 5), qualitative research cuts across disciplines and is represented in many areas of scholarship. We focus here on psychology, but recognize the substantial work done in related fields such as sociology, anthropology, social work, social policy, humanities, and the health sciences, in particular nursing. We cannot possibly do justice to the work that has been done in this arena in this one chapter. Entire volumes (c.f., Denzin \& Lincoln, 2013) are 
devoted to introducing researchers to these issues. We offer here what we hope is a concise and practical overview of some of the major philosophical assumptions that undergird qualitative research and shape its implementation today.

Once dominated by quantitative methods anchored in positivistic and post-positivistic research paradigms, a greater balance in the use of methodological and philosophical approaches is now being utilized in psychological research (Ponterotto, 2005; Rennie, Watson, \& Monteiro, 2002). The importance of qualitative research has long been justified by many on the basis of Dilthey's argument that the distinctive natures of natural science and human science called for different approaches: "We explain nature, but we understand psychic life" (1894/1977, p. 27; as cited in Wertz et al., p. 80). Today, qualitative methods are viewed as being particularly well-suited to addressing some of our most pressing issues and concerns, such as the influence of culture on psychological development and its role in psychological interventions (Ponterotto, Casas, Suzuki, \& Alexander, 2010). The rise of participatory action research (PAR), with its emphasis on social change and the empowerment of community participants (Kemmis \& McTaggart, 2005), has also required employing a range of qualitative approaches (i.e., focus groups, interviews, participant observation, photo-voice, and storytelling) to collecting data that contribute to the development of the kind of deeper understandings of the experiences of the participants needed to effect meaningful change.

The diversity of qualitative approaches can be dizzying and makes agreement about their appropriate use, in what forms, and according to what standards difficult, if not impossible. It can be challenging for "insiders" to navigate these issues, let alone the novice researcher wading into this terrain. Seemingly simple questions about sample size and composition or the specific steps one should take in data analysis and how to achieve reliable findings can provoke lengthy discussion and even heated debates, with researchers take opposing positions and rooting their justification for these in foundational principles of qualitative research. Even more maddening for some, such questions may simply yield a repeated singular and highly unsatisfying response of "it depends."

This seeming confusion can stem in part from differences in the purpose or aims of the research and in beliefs associated with core philosophies of science embedded within the varying approaches, namely ontology, epistemology, and axiology (Creswell, 2007; Hays \& Singh, 2012; Ponterotto, 2005). At its core, psychological research may be carried out with markedly distinct purposes, such as explaining and predicting aspects of the human experience, increasing our understanding of the lived experiences of different groups of people, or critiquing and changing the current conditions within which we live and strive to grow (Lincoln, Lynham, \& Guba, 2013). These different aims may also be carried out using approaches to research that rest on differing foundational assumptions about the nature of our world (ontology) and our knowledge about it (epistemology), as well as the role of values in the process of knowledge production (axiology), that are conceptualized by Hays and Singh (2012) as falling along separate continuums of beliefs.

Ontology is the study of the nature of reality. Within the context of qualitative research, ontology is discussed in terms of beliefs about the existence of some "universal truth" and about objectivity. At one end of the spectrum is a belief that reality is objective and that there are universal truths about reality that can be known. At the other end is a belief that reality is subjective and contextual, and a universal understanding of psychological experiences cannot be obtained because they must always be understood within the contexts within which they are embedded (Hays \& Singh, 2012). The crux of these viewpoints is also represented in the terms "emic" and "etic," which are often used in anthropology and cultural psychology. These terms have been used to capture the distinction between experience-near understandings of culture and human experience, or what an insider within a local context would recognize and resonate with, and more experience-distant conceptualizations or abstractions about cultural processes (e.g., Geertz, 1983). Etic can also be thought of as generalizations about human behavior that are universally true and emic as those that are contextually situated and not generalizable, such as local customs (Ponterotto, 2005).

Epistemology is the study of the process of knowing or "how we know what we know" (Guba \& Lincoln, 2008; Ponterotto, 2005). It is concerned with how we gain knowledge of what exists and the relationship between the knower-in this case the researcher-and the world. The researcher and research participant may be considered independent of one another. In this view, researchers can use rigorous, systematic approaches to studying 
participants objectively or without researcher bias. This results in much attention being paid to rigor in research, particularly in the form of strict adherence to generally accepted systematic approaches to enhancing objectivity and reducing researcher bias. On the other side of the continuum is an understanding of knowledge as being actively constructed by the researcher and participant, who exert mutual influence on one another. Rather than removing or guarding against researcher bias, the dynamic interaction between the researcher and participant is viewed as central to capturing the inherently contextualized experiences of the participant. Issues of rigor remain but take on different meanings and forms. The goal here is not to eliminate biasbecause that would be futile-but rather to enhance the trustworthiness of the findings by including and documenting multiple perspectives on the focus of the inquiry. In some cases, this might mean demonstrating that the researcher became immersed enough in the participants' experiences so as to credibly represent and interpret them. In others, this might involve triangulating the data sources and/or the investigators.

Axiology is concerned with how values and assumptions of the researcher influence the scientific process, as well as what actions the researcher takes with the research produced (Lincoln et al., 2013). What place do the emotions, expectations, and values of the researcher have in the research process? Should systematic steps be taken to ensure that the process is kept free of these so that they do not influence the participants and the results? Or is such a pursuit futile and the best a researcher can do is identify, describe, or even attempt to "bracket" (Wertz, 2011) his or her values? Much qualitative research today rests on the assumption that research is "radically relational" and is inevitably shaped, and even intentionally informed, by the researcher's orientation, values, and personal qualities (Wertz et al., 2011, p. 84). In research that seeks to change the status quo with regard to the unequal distribution of power and resources, such as in PAR, the researcher's experience is central to the process and may be key to achieving the intended outcomes of the research (Ponterotto, 2005). With regard to action, the positions range from researcher as distant observer of the study participants to researcher as change agent who is deliberately striving to achieve social justice through the work produced.

In some cases, the assumptions of a researcher may align more neatly along one side of these continuums. For example, a feminist researcher may hold that there are multiple truths and that knowledge is constructed in relationship with study participants, with the values and assumptions of the researcher integral to the construction of this knowledge. In others, the assumptions may be more mixed, such as a researcher who endorses a constructivist view of reality but views researcher reflexivity as less central to the research process. When these differing ontological, epistemological, and axiological stances go unacknowledged, the differences among qualitative approaches can seem as vast as those between quantitative and qualitative methods. As Camic, Rhodes, and Yardley (2003), among many, have argued, the principle that should unify us is the need for coherence between the nature of our questions and the methodological and philosophical approach taken to answering them.

In the next sections, we review the following major overarching philosophical approaches that guide and structure qualitative research: post-positivism, constructivism, critical theory, feminism, and queer theory. We offer a brief history of each of the approaches; consider the ontological, epistemological, and axiological assumptions on which they rest; and detail some of the distinguishing features while also attempting to capture some of the diversity within them. We also touch on some prominent applications of these approaches to qualitative research in psychology. We recognize that these approaches have been grouped and defined in varying ways and that they defy this sort of tidy categorization. Still, we draw some lines here in an effort to highlight distinctive ideas within each. Also included are discussions of applications of each of the approaches.

\section{Philosophical Approaches Post-Positivism}

Post-positivism grew out of the positivist view of science, and together these have dominated research in psychology for much of the field's history (Packer, 2011). Positivism rests on the ontological assumption that some objective truth or reality exists that is independent of our beliefs and constructions and can be ascertained through direct observation and experience. The efforts of science, thus, are put toward establishing universal laws of nature and, within psychology, universal laws of human development and experience. The attainment of this knowledge and our confidence in it depends on following systematic procedures through which claims about truth can be verified. Hypothesis generation and testing using valid measures of operationally 
defined variables are primary tools, and the goal is to be able, with confidence, to generalize the knowledge obtained to some larger general population. Post-positivism introduces the idea that hypotheses can never actually be proven beyond any doubt and that theory should tested in order to be falsified as well as verified. Issues of validity and reliability are of central importance in research within this paradigm, as are considerations of credible alternative hypotheses to explain the phenomenon being studied.

\section{HISTORY}

Post-positivism is rooted in logical positivism, a term coined by a group of scientists, mathematicians, and philosophers in the early 1900s known as the Vienna Circle. Building on the "positive philosophy" of Auguste Comte, but also emphasizing the importance of formal logic in scientific investigation, these thinkers determined that science required a systematic way of organizing our direct observations of experience and sought to inductively build laws of the natural world based on the construction of meaningful and unambiguous logical statements (Packer, 2011). Only statements of fact that could be verified in some way or tested empirically were considered to be meaningful in the scientific endeavor.

Karl Popper (1934/1959) objected to the idea that this kind of inductive construction and confirmation of factual, logical statements that were purportedly free from personal and theoretical bias could lead to certainty about the natural world. Instead, he argued that the laws of science had to be built through a process of falsification or testing of hypotheses. He argued that data disproving hypotheses are more definitive than those supporting them, as in any given study there is always the risk that the data gathered do not accurately or fully represent the real world being studied. The disconfirming case or cases may simply have not made it into the sample drawn for study.

\section{FOUNDATIONAL ASSUMPTIONS}

Post-positivism retains the belief in an observable external reality and the existence of universal truths but contends that a fully accurate representation of them can never be achieved with certitude (Popper, 1934/1959). Although things exist beyond our experience of them, it is recognized that our knowledge of this world is socially constructed. Bias is unavoidable. All observations are fallible because they are inherently laden with our individual and cultural biases. Although we can never get to the truth with any certainty, post-positivists contend that we should continually strive to come as close as we possibly can. Because all measurement is biased and introduces error, issues of reliability and validity are paramount. Great attention is paid to reducing or controlling for bias through the design of the research and the use of clearly defined techniques such as controls groups and multiple forms of measurement or triangulation. This attempt to remove or at least reduce bias extends to the subjectivity of the researcher as well as to the intentions of the research. The researcher is to remain as neutral as possible throughout the research process and should not engage in research in the service of advocacy for any particular position within their field.

From a post-positivist perspective, the existence of multiple worldviews does not extend into a belief in complete relativism and an incommensurability of perspectives - the belief that our differences in experiences and culture mean that we can never understand each other. Whereas we may never achieve objectivity in the true sense of the word, we can employ systematic ways of checking our biases both individually and collectively through engaging in the scientific enterprise within a community of people who critically review one another's work.

\section{IMPLICATIONS FOR RESEARCH METHODS}

Research rooted in post-positivism aims to explain psychological phenomenon by identifying factors that predict particular outcomes and the relationships between them. A priori theory about how things are related is used to guide the research, which then seeks to verify or falsify these theory-based ideas. Having confidence in the findings from such research rests on the rigor with which systematic steps in the research process are employed. Multiple levels of data analysis and taking steps to ensure validity contribute to the rigor of the research, and the results of these studies are typically written in the form of scientific reports similar in structure to that used for the reporting of quantitative studies.

\section{APPLICATION}

Grounded theory, a now widely used approach to qualitative research, as traditionally constructed aligns most closely with positivistic and post-positivistic assumptions (Bryant \& Charmaz, 2010). It was first developed by Glaser and Strauss (1967) in response to what they considered to be an overemphasis on hypothesis testing and the 
verification of theory in sociological research. They argued that the work of theory generation could not be complete and that all human experience was unlikely to be captured and accounted for by the existing grand theories of the time. They put forth grounded theory as a systematic approach to qualitative data collection and analysis to be carried out with the explicit purpose of discovering new theory from data or building new theory from the ground up, rather than by logical deductions from a priori assumptions. Although grounded theory turned the process of scientific inquiry in the post-positivist tradition on its head by beginning with the collection of data to use to ultimately build theory rather than collecting data to prove or disprove existing theory, the foundational assumptions on which traditional grounded theory rests are largely rooted in post-positivism. That said, constructive approaches to grounded theory have also been articulated and widely implemented (e.g., Charmaz, 2006), and others have argued that grounded theory techniques can be implemented using a variety of philosophical approaches (Birks \& Mills, 2011).

Traditional grounded theory "accepts that there is an external world that can be described, analyzed, explained and predicted: truth, but with a small $t$ " (Charmaz, 2000, p. 524). Part of the intent of grounded theory was to codify qualitative research methods and put forth a systematic set of explicit strategies for carrying out the research process, with the assumption being that following a systematic set of methods would lead to the discovery of real phenomena and the development of verifiable "theories" of them (Strauss \& Corbin, 1998). Such work, however, requires getting out into the field to collect rich data on which to build these theories. Some of the defining features of a grounded theory approach are (a) simultaneous data collection and analysis, (b) the development of codes from the data rather than from theory, (c) constant comparison of data at all levels of the data collection and analytic process, (d) theoretical sampling to serve the purpose of theory generation rather than representativeness of the sample, and (e) memo writing to define and elaborate on emerging categories and the relationships among them (Glaser \& Strauss, 1967; Strauss \& Corbin, 1998).

\section{Social Constructionism}

The tenets of the discipline throughout the twentieth century tended to place social constructionism at the opposite pole of experimental social psychology (Jost \& Kruglanski 2002), with the idea being that work in social psychology should fall on either end of the spectrum: you either do quantitative experiments or you engage in qualitative studies that are undergirded by a social constructionist paradigm. Although the two extremes have begun to meet in the middle in recent years, it is important to examine the role that the social constructionist perspective has played in shaping our thinking and work in the field of psychological research.

The notion of social construction first gained popularity in the United States after the publication of Berger and Luckmann's (1966) seminal book, The Social Construction of Reality. Relying on the work of Schutz, Berger and Luckmann argued that all of our understandings and knowledge are socially constructed. The idea is that we create our own reality through social interactions, relationships, and experiences. From the ontological perspective, reality is context- and socially relative, and therefore many realities can exist simultaneously (Berger \& Luckmann, 1966; Gergen, 1996). If our reality is constructed, then, too, our knowledge and meanings are derived from social interactions. Individuals hold them in their minds, but the epistemological notion of reality and meanings are not individual in nature but instead are constantly "negotiating meaning" (Gergen, 1996).

This has significant implications for both how we analyze the findings from past research in the field as well as how we shape future research projects. As Gergen (1996) states, "research findings don't have any meaning until they are interpreted" and interpretations "result from a process of negotiating meaning in the community (119)." The data do not reveal anything in or of themselves; instead, it is the way that psychologists utilize and interpret the data that reveals meaning. But again, it is not a truth that is revealed, or rather it is a truth, the truth that the researcher, given his or her experiences and knowledge, created while interacting with the social environment. Diverse and influential work, such as Milgram's (1974) experiment and Burr's (1998) work on the social construction of gender, illustrates the power of social interactions to frame and influence our understandings and realities.

Perhaps most importantly for our purposes, social construction highlights the social creation of identity. Identity creation and maintenance is work that we are constantly engaged in as individuals; we use Goffmanian (1955) performances and props to test how others interpret our identities, which then impacts how we think of our identity. This is also true for the related notion of self-worth. In an 
interesting study examining the social construction of identity among the homeless in Austin, Texas, Snow and Anderson (1987) found that there can be both a social identity (the identity that society gives you) and a personal identity (the identity you hold in your mind). Traditionally, these would be thought to align, but through a social construction approach Snow and Anderson (1987) argued that there are cases in which people cannot easily reconcile the public and personal. This has obvious implications for the field of social psychology and identity research.

Social construction, as defined by Berger and Luckmann (1966), suggests that reality is constantly in flux as it is negotiated and renegotiated through our experiences social worlds. From this core idea, other branches of social construction, such as symbolic interaction, phenomenology, and ethnomethodology, have evolved. Because they all fall under the social construction umbrella, it can be difficult at times to determine their differences. How does symbolic interactionism really differ from phenomenology, for example? The following sections lay out these three offshoots of social construction and attempt to present both their historical precedence as well as their current engagement with the discipline.

\section{SYMBOLIC INTERACTIONISM}

\section{History}

The symbolic interactionist approach was first developed in the early 1900s by George Herbert Mead (1913) at the University of Chicago. He was a member of the eminent group of sociologists (loosely termed at the time because he also taught philosophy) working as part of the Chicago School in the early to mid-1900s. The Chicago School came to be known in particular for the development of the symbolic interactionist approach to studying daily life. Mead argued that society and all its component parts-structures, interactions, and meanings-are developed through social interactions, thus macroanalyses can and should really be reduced to their smaller microlevel interactions. The theory was popular during the time of the Chicago School and was then expanded and adapted by Herbert Blumer in 1960s. Blumer did not like the emphasis placed on macrolevel structures that dominated most of the sociological research at the time and thought that symbolic interactionism offered an alternative theoretical framework. Blumer's work (1969) was resurrected as an empirical framework in the 1980s, and its popularity has ebbed and flowed since. One of the most renowned sociologists utilizing symbolic interactionism today is Sheldon Stryker at Indiana University.

\section{Foundational Assumptions}

Although Mead did not refer to the theory as such, symbolic interactionism is based on the overarching premise that all aspects of society are socially constituted. From macrolevel power structures to microlevel daily interactions, all are created through social interactions at various levels. Embedded in this perspective is the notion that meanings (about these power structures, interactions, etc.) are derived from social interactions. For both Mead and Blumer, the unit of analysis is the individual, not society or institutions. They were both reacting against the notion that social structures (i.e., socioeconomic stats) explain outcomes. Structures, according to symbolic interactionists, are just groups of people repeatedly engaged in interaction.

Our social interactions lead us to develop "shared meanings" (Sandstrom, Martin, \& Fine, 2006); through our interactions with others, we take on common definitions of emotions, experiences, and ways of acting. Thus, for example, gender norms may be taught, both consciously and unconsciously from early childhood; in this way, a female understands what it "means" to be a woman in her society without ever being explicitly told. A girl does not learn this in a bubble; rather, it is through her social interactions with others that she comes to understand what constitutes appropriate behavior, dress, appearance, and the like. She learns this through her experiences and the responses she gets from others.

Symbolic interactionism "stresses that people create, negotiate, and change social meanings through the process of interaction" (Sandstrom et al., 2006, p. 1). The key point here, for Blumer and others, is that meanings are constantly evolving. So, to follow the example just mentioned, our understanding of gender is not a fixed fact (because it might be different in different regions, religions, and time periods) but the result of previously experienced gendered interactions in our past. We take our previous interactions with us and apply them to the next interaction. Interactions, even with people we have just met, are not completely insulated events. Rather, each person brings to the interaction all of his or her previous interactions and meanings. Thus, a man and a woman in conversation will bring to this exchange all of their previously held ideas about femininity and masculinity, which they will use as 
a guide for navigating this new interaction. And of ultimate importance is Goffman's (1959) notion of the feedback loop; you act based on your prior understandings, receive feedback from your new partner, and then take this new feedback with you into your future interactions. As this process continues, you may alter your meanings, and potentially your behavior, over time. It is a process, not a set plan.

Because behavior and meaning are social constituted, so, too, is the self. Most symbolic interactionists would argue that there is no core/true individual identity. Rather, we engage in identity work in which take on different identities to manage the diversity of our social interactions. So, for example, in the classroom setting, one takes on the role of either professor or student. Out of this context, we may take on an entirely different identity, such as mother. None of these identities represents our "true self," but rather they are all appropriate context-specific roles. We base these roles on what Goffman (1959) called "the generalized other" or the group/people we interact with. So, we base our mothering role on our interactions with our children, our experiences with our own parents, friends, and media/cultural influences. As the "generalized other" changes, so do our identities. As a result of the primacy of social interactions, Mead's original theory is a very fluid one. Meanings are iterative because they are informed by our ongoing interactions.

\section{Implications for Research Methods}

The legacy of symbolic interactionism for research in psychology is an important one. First, the notion that all behaviors, from internal thoughts to outward interactions, are socially constituted has an impact on the psychological discourse. For researchers, this means that the participant cannot be looked at simply as an individual but rather as an individual in the social context. Thus, a person's thoughts and judgments are not solely the product of his or her own mind, but rather of his or her understandings based on social interactions (Sandstrom et al., 2006). And, additionally, one of the byproducts of social interaction is feedback about ourselves; we internalize others' perceptions of us, which can in turn influence our self-concept (Cook \& Douglas 1998). This has significant implications for any researchers studying mental health because it means that the mind is no longer a solely internal, individual unit of analysis. Our thoughts, ideas, hopes, and fears are all rooted in the social world and therefore have both social causes and consequences. Therefore, the "social act" should be the unit of analysis (Sandstrom et al., 2006).

Symbolic interactionists also highlight individual agency to form and change the world around us. Individuals "designate meanings, define situations and plan lines of action. In so doing, they actively construct the reality of their environment and exercise a measure of control over it" (Sandstrom et al., 2006, p. 6). We do this through the process of interacting, reflecting on, and evaluating interactions, and acting. This process is dynamic and, at least to some degree, controlled by the individual. There is no right or set meaning or type of interaction. Instead, we each create our own realities based on our understandings and meanings. Thus, it is still possible for two people to react to the same interaction very differently because each will bring his or her own history of social interactions and meanings to this experience.

Rooting the theory in individual meanings and experiences has implications for the types of research methods symbolic interactionists will utilize. The most commonly utilized approaches are ethnography, grounded theory, and narrative analysis because these methods allow the themes to emerge from the data, thereby preserving the individual experiences and realities. These methods more readily address the question of how people make meaning out of experiences in their lives and do not allow the researcher's assumptions and own set of meanings to dictate the findings that emerge from the data.

\section{Application}

The border between social psychology and sociology is often blurred by researchers in both disciplines' use of symbolic interactionism. In particular, Stryker (1987) argued that the movement in psychology away from behaviorism and toward a value placed on subjective experience is the result of the use of symbolic interactionism as a lens through which to examine psychological research. Thus, it is fair to say that the scope of symbolic interactionism's influence is far reaching within the field. One interesting study that took a symbolic interactionist approach is Ponticelli's (1999) study of former lesbians who, due to religious involvement in an ministry that does not acknowledge homosexuality, must reframe their sexual identities to align with their newly acquired religious beliefs. Ponticelli's research method involved eight months of participant observations, interviews, and material analysis, and her 
goal was to understand the ways that the ex-lesbians in her study construct a narrative of their sexuality. Symbolic interactionism lends itself well to this kind of study because it brings participants' own understandings and narratives to the study rather than the researcher's personal assessment of the participants' stories. Additionally, Ponticelli's study also incorporates a symbolic interactionist approach in its attempt to focus on the ways that meaning is created and adjusted over time.

\section{PHENOMENOLOGY}

\section{History}

Phenomenology was first established by Edmund Husserl in the early 1900s. It has subsequently been used as an approach within psychology as well as in other disciplines in the social sciences. Husserl's original goal was to find a way to conduct objective scientific analysis of subjective topics, such as emotion. Phenomenology, along with the ideologically similar symbolic interactionism, has been an important philosophical approach underpinning much of psychological research. In particular, phenomenology has influenced the Duquesne School as well as the experimental approaches utilized in psychological research. In spite of the influence of phenomenology within the field of psychology, over time, its theoretical premise has been challenged by some of the field's giants: James, Skinner, and Watson have at various times all challenged phenomenology and advocated a more scientific approach to the discipline of psychology. The debate continues today, and many researchers still question what constitutes phenomenological research as well as its merits as a philosophical framework.

\section{Foundational Assumptions}

Phenomenology is rooted in the notion that all of our knowledge and understanding of the world comes from our experiences (Hein \& Austin, 2001). At their core, there are significant similarities between phenomenology and symbolic interactionism in that both focus on the ways our engagement with society affects our worldviews. However, whereas symbolic interactionism focuses on the ways that social interactions affect our meaning, phenomenology takes the broader aim of studying experiences (phenomena). But, like symbolic interactionism, the focus is not on the events themselves, but rather on the ways in which we experience things and the meanings these experiences create for us. As Kockelmans (1973) writes, it is "bringing to light the usually hidden meanings which motivate the concrete modes of man's orientation toward the world" (p. 274). As such, those who utilize the phenomenological approach seek to make explicit the "taken-for-grantedness" assumptions that guide our experiences (Hein \& Austin, 2001, p. 6). In essence, there is no objective reality, but rather it is our experiences and our perceptions of these experiences (i.e., our lived experiences) that are our reality. Given that the meanings we create from our experiences are largely based on the social context (Smith, 2011), there is a clear link to symbolic interactionism.

Additionally, phenomenologists believe that behavior is a reflection of our previous experiences; we act in response to our temporal and spatial memories of past experiences or, as Keen (1975) writes, "behavior is an expression of being in the world" (p. 27). Thinking about behavior as a product of our past experiences forces us to consider action and individual agency as embedded in a broader social context. Related to this question of behavior is the notion of intentionality; namely, the idea that every experience is in response to or connected to some past experience. Thus, attempting to examine the experience as "in the moment" is, from a phenomenological perspective, missing the unique understandings the individual brought to the current experience.

\section{Implications for Research Methods}

As a research method, phenomenology involves studying how we make sense of our experiences or "participant perspectives" (Bogdan \& Biklen, 1998, p. 26). Therefore, as researchers, we cannot assume that we know what meanings people make of certain events. For example, even though we may think the standard response is to be sad after the death of a parent, we cannot presume that a participant in our study feels this or any other emotion. The job of the researcher is to uncover what it is people take for granted (i.e., what they might not even think to tell us in an interview and what we might not think to ask because we assume they think like we do). To do this, the researcher must first come to understand the assumptions and biases he or she brings to the research. Underlying phenomenological research is the notion of bracketing assumptions, which is the idea that, before we can conduct any analysis of our data, we must first explore our own biases or the "taken-for-grantedness" (Hein \& Austin, 2001, p. 6) that make up our unique perspectives. Of course, there is no way we, as researchers, can operate outside of our assumptions and experiences. However, the self-reflection for which 
phenomenologists advocate does at least charge the researcher with keeping these biases in mind when conducting analysis.

Approaching a research question with the assumption that experience forms the basis for behavior and understanding fundamentally lends itself to certain research methods. In particular, utilizing methods that emphasize gathering data on lived experience from the participant's perspective is essential. To that end, methods such as ethnomethodology, ethnography, and narrative analysis are particularly relevant for researchers utilizing the phenomenological approach because all of these methods focus on uncovering the meanings individuals give to their experiences.

\section{Application}

A great deal of the research in psychotherapy is rooted in the phenomenological approach because many scholars in this field see as their goal "discovering psychological meanings by identifying the essential psychological structure of an interviewee's description of an experience" (Camic et al., 2003, p. 8). A concrete example of this comes from Carl Rogers's client-centered therapy (1951). Rogers found that many of his patients struggled not with what actually happened-that is, the "in the moment" reality-but with their perceptions and feelings about what happened. As a result, therapy must be targeted to address the individual's set of perceptions and understandings. To follow up with the example of a person dealing with the death of a parent, a therapist cannot follow a preset protocol for helping the client because each patient's experiences and feelings about death will be different.

From the perspective of social psychology, the phenomenological approach has implications for how we conduct and think about research on identity. In its most general sense, phenomenology de-emphasizes the self as a unique individual, which has implications for the types of research questions we ask, as well as for the methods we utilize. A phenomenological study of identity allows for open-ended questions that allow participants to present, through the construction of a narrative for example, what identity means to them and how it functions in their lives. This is especially relevant for factors such as gender, race and ethnicity, and socioeconomic status, which, depending on our context, can constrain or enhance our experiences and interactions. One example of this type of work is Friedman, Friedlander, and Blustein's (2005) study that used a phenomenological approach to develop an understanding of how Jews construct their collective religious and ethnic identity as a highly assimilated but still distinct population within the United States.

A well-defined method with some roots in phenomenology (among other approaches) is consensual qualitative research (CQR; Hill, Knox, Thompson, Williams, Hess, \& Ladany, 2005; Hill, Thompson, \& Williams, 1997). It is a method for interview research that has been used in numerous studies in psychology, especially within counseling psychology. Consensual qualitative research is actually constructivist in ontology, in that it assumes multiple realities, and in epistemology because the researcher experience matters and informs interview question development. However, it also has post-positivistic leanings, with its emphasis on consensus among a team of researchers in the construction of findings, close adherence to a systematic approach, and interest in generalization and (Hill et al., 2005).

In CQR, consistent data are collected across participants through semistructured interviews and then analyzed by multiple "judges" who must come to a consensus about the meaning of the data. At least one "auditor" also checks the "primary team of judges" to work against the potential for groupthink. Data analysis is carried out in three steps. First, participant responses to the open-ended interview questions are divided into domains or topic areas. Then, core ideas, which are abstracts or brief "summaries of the data that capture the essence of what was said in fewer words and with greater clarity" are constructed within each domain for each individual case (Hill et al., 2005, p. 200). Finally, cross-case analysis is carried out by developing categories that describe the common themes reflected in the core ideas within domains across cases.

Consensus is at the core of the CQR method, with the assumption being that consideration of multiple perspectives brings us closer in our approximation of the "truth" and reduces the influence of researcher bias (Hill, Thompson, \& Williams, 1997). Using teams of three to five analysts, coders first look at the data independently and then come together to discuss their ideas until consensus about the single best representation of the data is reached. The goal here is not what is typically thought of as interrater reliability, wherein preagreement about how to code data is established and then carried out with the goal of achieving the highest levels of accuracy in 
agreement in coding. Rather, it is expected, and even hoped, that team members will begin with different ideas about the data so that the final product reflects and integrates multiple perspectives and is less fraught with individual bias. The potential for groupthink is minimized through the use of one or two additional team members who serve as auditors to review and check the primary team's interpretations and judgments. The auditors review the work of the primary team once the core ideas for each domain have been established consensually and then again when the cross-case categories have been determined. At each of these stages, the auditors review the raw material and provide comments back to the primary team who must then carefully consider each comment and determine through discussion whether to accept or reject each one.

\section{Critical Theory}

Critical theory as an approach represents a key postmodern paradigm and offers alternatives to the postmodernist and constructivist lenses. In the context of research, the application of critical theory emphasizes the ways by which the values of the researcher and those studied impact the social world. This point of view contributes to a larger shift in research over the past several decades (Kidd \& Kral, 2005), one that privileges meaning and requires a rethinking of knowledge (Goodman \& Fisher, 1995).

\section{HISTORY}

Critical theory has had many distinct historical phases that cross several generations. The birth of this paradigm is considered to have taken place through the Institute for Social Research at the University of Frankfurt am Main during 1929-1930. During this time, the arrival of the "Frankfurt School" philosophers and social theorists (Creswell, 2007), including Max Horkheimer, Theodor Adorno, and Herbert Marcuse, marked an idealistic, utopian vision that stretched beyond the more customary "positivist" tradition of the time. This emergence offered criticism to the status, structure, and goal of the traditional social sciences (Adorno et al., 1969). The German philosophers and social theorists of the Frankfurt School were influenced by the barbarism of World War I and what was perceived as the inhumanity of post-war capitalism so widespread in Europe at the time. During World War II, several key contributors to the School moved to the United States in an effort to escape the war. Once in the
United States, these thinkers were struck by the gulf between the stated progressive agenda within the United States and the very real differences between races and social classes present, in large part due to discrimination (Ponterotto, 2005).

According to these theorists, "critical" theory may be distinguished from "traditional" theories to the extent that it seeks human emancipation and a disruption of the status quo. Ontologically, critical theory challenges the idea that reality is natural and objective because reality is shaped by social, political, cultural, economic, ethnic, and gender-based forces into social structures. Instead, critical theorists assume that reality can only come to be known through a subjective frame and as shaped by values and mediated by power relations that are socially and historically constituted.

More recently, Jurgen Habermas's (1988; 1990) work on communicative reason and linguistic intersubjectivity has represented iconic work in critical theory in the more modern era. Habermas's work has enabled strategies of community building and social movements based on his work in communication. This work has not taken place without scrutiny, however. Theorists such as Nikolas Kompridis have opposed some of Habermas's ideas (Kompridis, 2006), claiming that these recent approaches have undermined the original aims of social change espoused by critical theory, particularly in terms of the critique of modern capitalism.

\section{FOUNDATIONAL ASSUMPTIONS}

According to Horkheimer, a critical theory is adequate only if it is explanatory, practical, and normative (1972). In other words, it has to address what is wrong with current social reality, identify the actors to change it, provide clear norms for criticism, and identify practical goals for social transformation. The orientation of this theory is toward transformation, traditionally of capitalism into a "real democracy".

Foundation ideals are based on a fundamental struggle for equality and social justice. Knowledge is used to emancipate the oppressed, and "validity is found when research creates action" (Lincoln, Lynham, \& Guba, 2011, p. 114). Given this definition, a number of "critical theories" have been developed to demonstrate differences in power in the areas of gender, race and ethnicity, class, sexual orientation, and disabilities, many of which have emerged in connection with the social movements associated with these areas, particularly in the United States. In short, a critical theory provides the 
basis and groundwork for research aimed at decreasing domination and increasing freedom.

Critical theory by and large rejects the assumption that a scientific or objective basis of criticism needs to be grounded in a grand theory. Rather, epistemologically, critical theory privileges agents' own knowledge and understandings, with an assumption that these understandings can be a basis for social criticism in themselves. In other words, theories can have "a relative legitimacy" (Habermas, 1988 , p. 3). Habermas also argues that, relative to other existing theories, the role of critical theory is to unify these multiple theories, considering their varied methods and presuppositions (Habermas, 1988). Given this role, it stands to reason that any social scientific method or explanation-producing theory can be potentially critical.

Similarly, in critical theory, the relationship between researcher and participant is transactional, subjective, and dialectic. In other words, what can be known is inextricably tied to the interaction between an investigator and an object or group. Insofar as one can separate oneself from marginalized groups in an effort to remain "objective," one removes oneself from one's "share" of the social condition studied, likely perpetuating the inequalities that contribute to the adverse social conditions often of interest to social scientists.

Researchers who employ critical theory take values a step further than constructivists do in that they hope and expect their value biases to influence the research process and outcome. More specifically, because critical theory concerns itself with unequal distributions of power and the resultant oppression of subjugated groups, a preset goal of the research is to empower participants to transform the status quo and emancipate themselves from ongoing oppression. Thus, critical theorist researchers acknowledge at the outset that they expect results to document the high levels of stress or disadvantage of the group under study. Beyond this, such researchers aim to use the results and report of the study in some way to advocate for improvement of the examined group.

\section{IMPLICATIONS FOR RESEARCH METHODS}

Critical theorists, given their stance on the importance of researcher-participant interaction and the significance of understanding values as influencing the reality under study, more often use naturalistic designs in which the researcher is engaged in the daily life of participants. Critical theoretical approaches tend to rely on dialogic methods, which may combine data collection methods (e.g., participant observation, in-depth interviewing, first-person written reports) with opportunity for reflection. This approach intentionally invites a questioning of the "natural" status quo and order and an exploration of the tensions that characterize the social issue under exploration. Inherently challenging, this approach values transparency and welcomes opportunities for alternative paradigms to be considered as part of the learning process itself.

Methodologically, contexts are not merely conceptualized as "variables," but as essential parts of subjectivity according to critical theory. In terms of the field of psychology, this approach invites us to consider the role of research in terms of how liberation might take shape across the lifespan. Qualitative approaches in which a researcher's social justice values help direct inquiry, such as PAR (Kidd \& Kral, 2005), provide ample example of critical theory at work in the research context.

\section{APPLICATION IN THE FIELD}

Participatory action research is a form of action research anchored in the belief that the research process itself serves as a mechanism for social change. Participatory action research is an approach focused on critical theory because, at its core, PAR is geared toward empowerment of participants that leads to emancipation from oppression and enhanced quality of life. In laypersons' terms, "you get people affected by a problem together, figure out what is going on as a group, and then do something about it" (Kidd \& Kral, 2005, p. 187).

According to Kemmis and McTaggart (2005), PAR often involves a cycle of self-reflection and action in addressing a community problem. Participants and researchers establish a collaborative relationship as they ask critical questions about the current life situation. This dialogue moves the group to action as they develop knowledge and further explore the problem and how it can be addressed. In this way, collaborators using PAR begin to set a stage of social action to instigate change.

The process of change emerges and shifts as part of the self-reflective cycles, but typically is not predetermined by a clear series of procedural and analytic steps. Instead, during the reflective and action spiral, PAR investigators rely on a wide variety of methods and procedures as they gradually better understand the needs of the community. As such, many studies that use PAR take on varied methods such as storytelling, sharing experiences, individual and focus group interviews, participant observation, 
drawings, and even the more structured qualitative interview or quantitative survey as the need merits.

When engaged in a PAR process, study participants are expected to participate fully. However, the creation of such participatory contexts is very challenging and time-consuming, and is not the norm (Kidd \& Kral, 2005). Disempowered groups are seldom given the opportunity and at times are discouraged from this type of action. Further compounding this problem is the tendency for established forums (e.g., academia) to claim exclusive ownership of methods of knowledge gathering and avenues for change. All of these challenges further lend the process of PAR to be informed by critical theory. As a specific example, Dentith, Measor, and O'Malley (2012) outline the practice of using critical theory across three separate research projects involving young people facing various life difficulties and vulnerabilities. In so doing, they highlight the dilemmas they face in doing so within the context of more traditional, positivist approaches frequently favored in academic research settings.

Participatory action research is somewhat new to the field of psychology and has not historically been utilized frequently in this field. This is likely at least in part due to the axiology of PAR as a critical theory method that advocates a value-directed (rather than value-neutral post-positivism or value-bracketed constructivism) stance. Traditionally trained psychologists may be made initially uncomfortable by research that is value mediated because psychological training often conceives of research as objective, in which participants are studied without changing them or the researchers.

\section{Feminist Theories}

Feminist theories are used to frame and understand research approaches across a range of disciplines and social problems. They developed in part in response to prevailing ideas that more traditional scientific inquiry tended to exclude women from inquiry and deny women epistemic authority (Anderson, 1995). They are often associated with critical theory, although they have been considered by some to be separate (Crotty, 1998), yet closely related, within the epistemological continuum.

\section{HISTORY}

Informed by the political ideologies of the 1970 s women's movement, feminist scholars sought to reinterpret and modify concepts within the philosophy of science to create feminist approaches to research. Originally fueled by activism, feminism as an academic focus has developed significantly from the 1980s until the present. According to feminist paradigms, the traditional philosophy of science has tended to produce theories that represent women (or their activities and interests) as inferior to their male counterparts. Further, "feminine" cognitive styles and modes of knowledge have been denigrated by traditional inquiry (Anderson, 1995), producing knowledge that is not relevant to people in subordinate positions and/or that reinforces unequal power dynamics, particularly as it relates to gender.

\section{FOUNDATIONAL ASSUMPTIONS}

Feminist theories "place gender at the center of inquiry," and yet "increasingly incorporate multiple... intersectionalities of identity," including sexuality, race, religion, and social class (Marshall \& Rossman, 2010, p. 27). Similar to critical theory, the larger aim of feminist theories is to turn thought into action (Marshall \& Rossman, 2010), in this case by focusing on the issues faced by women and other often marginalized groups.

Epistemologically, feminist theories focus on the accounts of women (and other historically marginalized groups) as legitimate and core sources of knowledge. Of note, feminist theories are not distinguished so much by their substantive topic (e.g., women's issues, gender, reproductive rights, etc.) or by the gender of the researcher (i.e., male or female) but rather by their orientation and guiding philosophy on epistemology and research creation (e.g., methodology).

\section{IMPLICATIONS FOR RESEARCH METHODS}

Over the past two decades, feminist scholars have developed alternative epistemologies to guide the process of doing research. Feminist methodologies attempt to eradicate sexist bias in research while capturing women's voices, particularly those consistent with feminist ideals. Epistemologically, feminist theories privilege women's experiences as not only legitimate, but also as important and revealing bases of knowledge. Work guided by feminist theories often aims to employ qualitative methodologies toward the exploration of power imbalances, starting with that between the researcher and researched (Marshall \& Rossman, 2010), so as to engender trust and collect accurate data. Research informed by feminist theory, like critical theory more broadly, also challenges academia traditionally due to its value of application of research to lived experiences (Smart, 2009), particularly among those who are oppressed. 
Thus, feminist theories mirror the core values of critical theory in emphasizing the mutual learning between the researcher and the researched, an exchange that is critical to the emancipation of disenfranchised or overlooked groups.

Feminist research has emphasized the importance of exploring the day-to-day experiences of marginalized groups, particularly women. Qualitative approaches are particularly well-suited to capturing the "messiness" of these daily experiences because these methods can account for emotions, as well as for other less tangible aspects of experience, in data collection. Often, feminist theories invite more traditional forms of qualitative data collection (e.g., interviewing, focus groups, ethnography) to be adapted to be more consistent with feminist ideology.

\section{APPLICATION}

As referenced earlier, a feminist approach to research can be employed across the social as well as physical sciences and beyond. For the most part, researchers employing this approach attempt to eradicate sexist bias in research while seeking to capture women's voices, particularly as they apply to the day-to-day experiences of everyday life. This angle lends itself well to studies such as those examining the experiences of domestic workers and domestic violence. Core to the use of feminist theory is the understanding that ways of knowing, or epistemologies, are constantly evolving as knowledge grows and as the "knowers" expand in scope. Thus, bodies of research, as they make use of a feminist lens, may find that the social problem under study increases the complexity of the problem under study. This is characteristic of feminist methodologies. However, such an approach is also characterized by reducing the hierarchical relationship between researchers and their participants to facilitate trust and disclosure and recognizing and reflecting on the emotionality of women's lives.

\section{Queer Theory HISTORY}

With the rise of the gay liberation movement in the post-Stonewall era, gay and lesbian perspectives began to contribute to politics, philosophy, and social theory. Initially, these were often connected to feminist ideology. However, in the late 1980s and early 1990s, queer theory was developed as its own framework. The term "queer," as opposed to "gay and lesbian," also distinguished the theory from those that preceded it, specifically gay liberation theories. Similar to feminist theories, queer theory was accompanied by social movements, and its emergence evolved in part as a reaction to the marginalization of the LBGTQ community and the ways by which "science" had historically been used against them (Minton, 1997).

Queer theory found a more natural home in qualitative research because this form had historically been less focused on objective reality and more on subjective experiences (Downing \& Gillett, 2011). However, its emergence has occurred within an ongoing evolution in terms of how we consider sexuality and marginalization in research and in society at large. In the early 1900 s, the scientific examination of those who were in same-sex relationships was perpetually challenged by the stigma and silence faced by this group. In short, this population was hard to identify and find, much less research. The second half of the twentieth century, however, shifted this as lesbian and gay studies expanded exponentially (Gamson, 2000), focusing explicitly on the lives of those who identify as gay or lesbian. Queer theory, a more recent arrival on the scene, has introduced a post-structuralist critique by suggesting that the self cannot and should not be identified by sexuality or sexual orientation by itself, thereby challenging the importance of studying sexuality as a "subject" of inquiry. Although the tension proposed by these shifts is often applauded within the qualitative research world (e.g., Gamson, 2000), it is this context in which queer theory has emerged.

\section{FOUNDATIONAL ASSUMPTIONS}

Queer theory was separate from gay liberation theories in several ways. First, queer theory defined itself as not specific only to sexuality. Instead, queer theory does not refer to a nature, be it sexual or otherwise, but rather as a relational construct. "Queer" refers specifically to being "outside the norm"; this norm can vary relative to context. In other words, "Queer is... whatever is at odds with the normal, the legitimate, the dominant. There is nothing in particular to which it necessarily refers. It is an identity without an essence" (Halperin, 1995, p. 62; emphasis in the original).

Because queer theory does not suggest a specific nature or essence, it therefore is inclusive of those who may express themselves outside any norm, including that of the gay and lesbian community. In other words, sadomasochism, perhaps marginalized by some constructs, is not so according to queer theory. Additionally, this lack of focus on a specific 
essence allows gays and lesbians to identify by their sexuality or by any other aspect of their identity, thereby placing the focus on personal meaning, as opposed to societally ascribed labels.

\section{IMPLICATIONS FOR RESEARCH METHODS}

A central claim of queer theorists, which is that identity is understood exclusively as a social construct (rather than given by nature), significantly affects how research is carried out within this approach. Most immediately, it implies that research needs to be evaluated for biases that privilege heterosexuality (Butler, 1990; 1993), however subtle. Based on the concern that queer theory places on false dichotomies (e.g., "closeted" and "out," etc.), this theory also is critical of other dichotomies implied in research, particularly as it relates to assumptions regarding what is natural or artificial and what is masculine versus feminine. Instead, queer theory emphasizes the importance of understanding categories more fluidly, an approach that lends itself more toward qualitative methods, which seek to explore social phenomena with an eye toward complexity rather than standardization.

\section{APPLICATION}

Queer theory has been applied to multiple social problems and developmental issues. However, it is most often applied to questions concerning empowerment, resistance to domination (e.g., heterosexism, homophobia), gender identity and marginalization due to gender, sexual orientation, or sexual behavior. Because queer theory is concerned with the nonessential nature of sexual identity, this theory pushes the field to consider identity from multiple perspectives, and invites cultural as well as race-related inquiry.

\section{Conclusion and Future Directions}

It is impossible to fully represent the richness of any one of these philosophical approaches in a chapter such as this one. We have instead tried to convey a sense of the breadth of the field and to illuminate at least some of the meaningful distinctions in the major approaches to qualitative research in psychology today. In this last section, we turn our attention to the future and identify three overarching, interrelated, and contested issues with which the field is being confronted and will be compelled to address as we move forward: retaining the rich diversity that has defined the field, the articulation of recognizable standards for qualitative research, and the commensurability of differing approaches.
The contested nature of these issues stems in part from the very diversity of philosophical approaches that has defined the field. Here, again, we cannot possibly represent the considerable thought behind and debate around each of these matters. Rather, we simply raise and mark them at this time.

The diversity of approaches represented in the field of qualitative research today speaks to the strength of the movement and bodes well for our efforts to both advance and deepen our understanding of the psychological world. As Ann Hartman (1990) wrote many years ago, "each way of knowing deepens our understanding and adds another dimension to our view of the world" (p. 3). Just as no single research design or data collection method can adequately capture the multidimensional nature of human psychology, no one philosophical approach can suitably guide our efforts to address the full range of questions that need to be pursued to develop the knowledge needed "to benefit society and improve people's lives" (American Psychological Association, 2013).

However, this diversity in approaches to qualitative research also creates significant tensions and makes attempts to "define" the field quite challenging. Despite the substantial work done by many scholars (c.f. Denzin \& Lincoln, 2013) to delineate these contrasting perspectives and approaches, a lack of awareness remains, especially (but not exclusively) among those not well-versed in qualitative methods. The predictable misunderstandings and strong differences in beliefs about what is "credible" research that can result continue to plague those of us who practice qualitative research as we strive to get our work funded and published more widely. Peer reviews of our work can often be riddled with contradictory assessments of its rigor and even of its basic value or contribution. (c.f. Ceglowski, Bacigalupa, \& Peck, 2011).

Continued efforts to make clear the diversity of approaches, the philosophical assumptions guiding these, and the particular contributions the differing approaches make to our understanding of psychology are critical. We must be cautious about making general claims about rigor and the "right" way to do qualitative research that are actually framed within our own narrower terms or experience with certain approaches. Keeping the richness of the field alive will require discipline on all of our parts to respond to questions about how best to go about engaging in high quality qualitative research or evaluating the quality of the work of others by first acknowledging "it depends" and then inquiring about the philosophical approach, aims, and context of the work. 
One of the biggest challenges before us is the continued articulation of recognizable standards for qualitative research that represent, and which ideally can be applied to, the full range of approaches. The very differences in purpose and aims and in philosophical approaches that comprise the rich field of qualitative research today makes such efforts seem impossible. However, ignoring this task in the era of what has been called the scientifically based research movement (National Research Council, 2002; Torrance, 2008), defined largely in terms of experimental design and methods and with randomized controlled trials heralded as the "gold standard," leaves the array of approaches that do not readily fit this mold highly vulnerable. But what is the best way to address these complex and high-stakes issues?

Researchers taking a more post-positivistic approach have argued that there are separate but parallel sets of standards for validity and reliability in qualitative and quantitative research (e.g., Hammersley, 1992; Kuzel \& Engel, 2001). Some constructivists have put forth that a common set of standards can be established but because the foundational philosophical approaches between post-positivism and constructivism are so different, a separate and distinct set of criteria need to be applied. Models using concepts such as trustworthiness, transferability, and authenticity have been developed (e.g., Guba \& Lincoln, 1989), and it is estimated that more than 100 quality appraisal forms have been put forth (Saini \& Shlonsky, 2012). Unfortunately, most do not make clear the philosophical assumptions that undergird them (Saini \& Shlonsky, 2012), which unfortunately further muddies the water. Moreover, other adherents to constructivist approaches hold that the contextual and relational nature of knowledge construction precludes the possibility of establishing such standards (e.g., Lincoln, 1995; Schwandt, 1996). Finally, many working from within critical theory and related approaches suggest that such standards are inevitably formed by the power structures in which they are housed, thereby potentially further perpetuating the inequalities the research aims to address or study (e.g., Garrett \& Hodkinson, 1998). Furthermore, they assert that the quality of the research should be based on an assessment of whether it empowered participants to effect meaningful and lasting changes (Correa, 2013).

Some have tried to resolve these tensions by suggesting guidelines they believe account for and are applicable across the diversity of approaches to qualitative research (e.g., Drisko, 1997; Saini
\& Shlonsky, 2012; Tracy, 2010). These guidelines focus on the different components of the research process, such as clear identification of philosophical approach and aims of the research, specification of methods and congruence between these and the stated philosophical approach and aims, and transparency and clarity in sampling, data collection, and data analytic procedures. Although the imperative to tackle these issues is clear, the way forward to doing this is less so. Should we push further toward agreeing on a shared set of standards that can be applied across traditions, or invest in more localized ones tailored specifically to particular approaches (e.g., narrative analysis) and developed by scholars practicing these (Preissle, 2013), or both? How might the myriad elements of research, including the many gatekeeping activities in the research and scholarship enterprise from funding through publication of research findings, address and accommodate these standards in their expectations and processes? What is clear is that the diversity of approaches to qualitative research must be fully represented in any efforts to further define and move the field forward on this front.

Embracing and fully representing the diversity of approaches and coming to terms with standards for them stills leaves unaddressed a third concern for the field moving forward, namely what has been referred to as the commensurability of approaches. That is, whether approaches rooted in the differing philosophical approaches can be "retrofitted to each other in ways that make the simultaneously practice of both possible" (Lincoln et al., 2013, p. 238). Some, such as critical and feminist theorists, have argued that epistemological differences between methods can render research paradigms incompatible (Lincoln et al., 2013). Others have dismissed assertions about irreconcilable differences between philosophical approaches and research paradigms and argue for what they call a "pragmatic" approach, particularly in the service of carrying out mixed-methods research (e.g., Creswell, 2009; Creswell \& Clark, 2007; Maxcy, 2003). Lincoln, Lynham, and Guba (2013) take a middle position and offer a "cautious" endorsement of the commensurability of approaches. They assert that some approaches share some elements that are similar or strongly related and therefore can be effectively and meaningfully combined, whereas others are more "contradictory and mutually exclusive" (p. 239). Preissle (2013), in her consideration of the future of the field, makes a pragmatic argument of a different sort for commensurability. Citing the work of her 
students that has combined approaches in unconventional yet highly productive ways, she observes that the novice scholars of today are "challenging, even transgressing, epistemological and theoretical boundaries" that will ultimately move research forward in unexpected ways" (p. 536).

There is nothing new about these questions. They have been debated for decades now, and clarity seems no nearer. What has changed is the climate. It is at once more open to qualitative methods than ever before and less accommodating of the rich diversity among the approaches taken to this work. Increasing numbers of graduate students are being trained in multiple methodologies. Although, unfortunately, there does not yet appear to be a cry for purely qualitative studies on the horizon, most major funding sources are at least indicating a preference for the use of multiple methods, in some cases even quite strongly so. Qualitative studies can be found in journals of differing ilk, not just within the confines of those dedicated to publishing qualitative research. However, what is deemed acceptable or "credible" qualitative research is narrowing. In the parlance of the old expression "a little knowledge is a dangerous thing," the widening exposure and reach of qualitative work means that many more scholars are encountering and engaging with it in some way; these scholars often do not realize that what they know is but a small slice of a now large and longstanding field. Researchers outside the field of qualitative research who participate in setting the standards for research more broadly may be friendly to particular kinds of approaches, such as seeing a place for qualitative work only in the exploration of new areas of inquiry to offer "thick description" and examples or to complement or round out the quantitative findings, but much less so to stand-alone work or work aimed at explicating processes and mechanisms at work in human psychology. Scholars from within who are joining in the work of setting the standards of research can sometimes allow certain kinds of qualitative research to stand for the field, which can serve to belie and even shut out other, often more transgressive forms. These perhaps seemingly old and familiar questions about philosophies of science, rigor, and commensurability are alive and well, taking new forms, and they are, in some ways, more important now than ever before.

\section{References}

Adorno, T., Albert, R., Dahrendorf, H., Habermas, J., Pilot, H., \& Popper, K. (1969). The positivist dispute in German sociology. London: Heinemann.
American Psychological Association (APA). (2013). About APA. Retrieved from http://www.apa.org/about/3/27/2013

Anderson, E. (1995). Feminist epistemology: An interpretation and defense. Hypatia, 10, 50-84.

Berger, P., \& Luckmann, T. (1966). The social construction of reality: A Treatise in the sociology of knowledge. New York: Anchor Books.

Birks, M., \& Mills, J. (2011). Grounded theory: A practical guide. Thousand Oaks, CA: Sage Publications.

Blumer, H. (1969). Symbolic Interactionism: Perspectives and Method. Englewood Cliffs: NJ: Prentice-Hall, Inc.

Bogdan, R. C., \& Biklen, S. K. (1998). Foundations of qualitative research in education (3rd ed.). Boston: Allyn \& Bacon.

Bogdan, R. C., \& Biklen, S. K. (1998). Foundations of qualitative research in education (3rd ed.). Boston: Allyn \& Bacon.

Bryant, A., \& Charmaz, K. (2010). Grounded theory in historical perspective: An epistemological account. In K. Charmaz \& A. Bryant (Eds.), Handbook of grounded theory (pp. 31- 57). Thousand Oaks, CA: Sage Publications.

Burr, Vi. (1998). Gender and social psychology. London: Routledge.

Butler, J. (1990). Gender trouble. London: Routledge.

Butler, J. (1993). Bodies that Matter: On the discursive limits of "sex". London: Routledge.

Camic, P. M., Rhodes, J. E., \& Yardley, L. (2003). Naming the stars: Integrating qualitative methods into psychological research. In P. M. Camic, J. E. Rhodes, \& L. Yardley (Eds.), Qualitative research in psychology: Expanding perspectives in methodology and design (pp. 3-15). Washington, DC: American Psychological Association.

Ceglowski, D., Bacigalupa, C., \& Peck, E. (2011). Aced out: Censorship of qualitative research in the age of "scientifically based research”. Qualitative Inquiry, 17(8), 679-686.

Charmaz, K. (2000). Grounded theory: Objectivist and constructivist methods. In N. K. Denzin \& Y. S. Lincoln (Eds.), Handbook of qualitative research (2nd ed., pp. 509-535). Thousand Oaks, CA; Sage Publications.

Charmaz, K. (2006). Constructing grounded theory: A practical guide through qualitative research. Thousand Oaks, CA: Sage Publications.

Cook, W. L., \& Douglas, E. M. (1998). The looking-glass self in family context: A social relational analysis. Journal of Family Psychology, 12(2), 299-309.

Correa, F. P. (2013). The evaluation of qualitative research: A reflection from a justice perspective. Qualitative Inquiry, 19(3), 209-218.

Creswell, J. W. (2007). Qualitative inquiry and research design: Choosing among five approaches. Thousand Oaks, CA: Sage Publications.

Creswell, J. W. (2009). Research design: Qualitative, quantitative, and mixed methods approaches. Thousand Oaks, CA: Sage Publications.

Creswell, J. W., \& Clark, V. L. P. (2007). Designing and conducting mixed methods research. Thousand Oaks, CA: Sage Publications.

Crotty, M. (1998). The foundations of social research: Meaning and perspective in the research process. Thousand Oaks, CA: Sage Publications.

Dentith, A. M., Measor, L., \& O’Malley, M. P. (2012). The research imagination amid dilemmas of engaging young people in critical participatory work. Forum Qualitative Sozialforschung/Forum: Qualitative Social Research, 13(1), Art 17. Retrieved from http://www.qualitative-research.net/ index.php/fqs/article/view/1788/3309 
Denzin, N. K., \& Lincoln, Y. S. (2013). The landscape of qualitative research (4th ed). Thousand Oaks, CA: Sage.

Downing, L., \& Gillett, R. (2011). Viewing critical psychology through the lens of queer. Psychology \& Sexuality, 2(1), 4-15.

Dilthey, W. (1977). Ideas concerning a descriptive and analytic psychology (1894). In Descriptive psychology and historical understanding (R. M. Zaner \& K. L. Heiges, Trans.). The Hague: Martinus Nijhoff.

Drisko, J. (1997). Strengthening qualitative studies and reports: Standards to enhance academic integrity. Journal of Social Work Education, 33, 1-13.

Friedman, M., Friedlander, M., \& Blustein, D. (2005). Toward an understanding of Jewish identity: A phenomenological study. Journal of Counseling Psychology, 52(1), 77-83.

Gamson, J. (2000). Sexualities, queer theory, and qualitative research. In N. Denzin \& Y. Lincoln (Eds.), Handbook of qualitative research (2nd ed.). (pp. 347-365). Thousand Oaks, CA: Sage.

Garrett, D., \& Hodkinson, P. (1998). Can there be criteria for selecting research criteria? A hermeneutical analysis of an inescapable dilemma. Qualitative Inquiry, 4(4), 515-539.

Geertz, C. (1983). Local knowledge. New York: Basic Books.

Gergen, K. J. (1996). Social psychology as social construction: The emerging vision. In C. McGarty \& A. Haslam (Eds.), For the message of social psychology: Perspectives on mind in society (pp. 113-128). Oxford: Blackwell.

Glaser, B. G. \& Strauss, A. L. (1967): The discovery of grounded theory: Strategies for qualitative research. Chicago: Aldine.

Goffman, E. (1959). The presentation of self in everyday life. New York: Anchor Books, Doubleday.

Goodman, F., \& Fisher, W. (Eds.). (1995). Rethinking knowledge: Reflections across the disciplines. Albany, NY: State University of New York Press.

Guba, E. G., \& Lincoln, Y. S. (1989). Fourth generation evaluation. Thousand Oaks, CA: Sage Publications.

Habermas, J. (1988). On the logic of the socialsciences. (S. W. Nicholsen $\&$ J. A. Stark, Trans.). Cambridge, MA: MIT Press.

Habermas, J. (1990). Moral consciousness and communicative action. Cambridge, MA: MIT Press.

Halperin, D. M. (1995). Saint Foucault: Towards a gay hagiography. New York: Oxford University Press.

Hammersley, M. (1992). What's wrong with ethnography? London: Routledge.

Hartman, A. (1990). Many ways of knowing. Social Work, 35(1), 3-4.

Hays, D. G., \& Singh, A. A. (2012). Qualitative inquiry in clinical and educational settings. New York: Guilford Press.

Hein, S. F., \& Austin, W. J. (2001). Empirical and hermeneutic approaches to phenomenological research in psychology: A comparison. Psychological Methods, 4(1), 3-17.

Hill, C. E., Knox, S., Thompson, B. J., Williams, E. N., Hess, S. A., \& Ladany, N. (2005). Consensual qualitative research: An update. Journal of Counseling Psychology, 52(2), 196-205.

Hill, C. E., Thompson, B. J., \& Williams, E. N. (1997). A guide to conducting consensual qualitative research. The counseling psychologist, 25(4), 517-572.

Horkheimer, M. (1972). Critical theory: Selected essays. New York: Continuum International Publishing Group.

Jost, J. T., \& Kruglanski, A. W. (2002). The estrangement of social constructionism and experimental social psychology: History of the rift and prospects for reconciliation. Personality and Social Psychology Review, 6(3), 168-187.
Keen, E. (1975). A primer in phenomenological psychology. Lanham, MD: University Press of America.

Kemmis, S., \& McTaggart, R. (2005). Participatory action research: Communicative action and the public sphere. In N. K. Denzin \& Y. S. Lincoln (Eds.), The Sage handbook of qualitative research (3rd ed., pp. 559-604). Thousand Oaks, CA: Sage Publications.

Kidd, S. A., \& Kral, M. J. (2005). Practicing participatory research. Journal of Counseling Psychology, 52(2), 187-195.

Kockelmans, J. (1973). Theoretical Problems in Phenomenological Psychology. In M. Natanson (Ed.). Phenomenology and the Social Sciences. (Vol. 1, pp. 225-280). Evanston, IL: Northwestern University Press.

Kompridis, N. (2006). Critique and disclosure: Critical theory between past and future. Cambridge, MA: MIT Press.

Kuzel, A. \& Engel, J. (2001). Some pragmatic thought on evaluating qualitative health research. In J. Morse, J. Swanson, \& A. Kuzel (Eds.), The Nature of Qualitative Evidence (pp. 114-138). Thousand Oaks, CA: Sage.

Lincoln, Y. S. (1995). Emerging criteria for quality in qualitative and interpretive research. Qualitative Inquiry, 1, 275-289.

Lincoln, Y. S., Lynham, S. A., \& Guba, E. G. (2013). Paradigmatic controversies, contradictions, and emerging confluences revisited. In N. K. Denzin \& Y. S. Lincoln (Eds.), The landscape of qualitative research (4th ed., pp. 199265). Thousand Oaks, CA: Sage Publications.

Lincoln, Y. S., Lynham, S. A., \& Guba, E. G. (2011). Paradigmatic controversies, contradictions, and emerging confluences revisited. In N. K. Denzin \& Y. S. Lincoln (Eds.), The SAGE handbook of qualitative research (4th ed., pp. 97-128). Thousand Oaks, CA: Sage Publications.

Marshall, C., \& Rossman, G. B. (2010). Designing qualitative research (5th ed.). Thousand Oaks, CA: Sage Publications.

Maxcy, S. J. (2003). Pragmatic threads in mixed methods research in the social sciences: The search for multiple modes of inquiry and the end of the philosophy of formalism. In C. Teddlie \& A. Tashakkori (Eds.), Handbook of mixed methods in social \& behavioral research (pp. 51-89). Thousand Oaks, CA: Sage Publications.

Mead, G. H. (1913). The social self. Journal of Philosophy, Psychology and Scientific Methods, 10(14), 374-380.

Milgram, S. (1974). Obedience to Authority: An Experimental View. New York, NY: HarperPerennial.

Minton, H. L. (1997). Queer theory: Historical roots and implications for psychology. Theory \& Psychology, 7(3), 337-353.

National Research Council (NRC). (2002). Scientific research in education. Committee on Scientific Principles for Education Research. (R. J. Shavelson, \& L. Towne, Eds.). Center for Education. Division of Behavioral and Social Sciences and Education. Washington, DC: National Academy Press.

Packer, M. J. (2011). The science of qualitative research. New York: Cambridge University Press.

Ponterotto, J. G. (2005). Qualitative research in counseling psychology: A primer on research paradigms and philosophy of science. Journal of Counseling Psychology, 52(2), 126-136.

Ponterotto, J. G., Casas, J. M., Suzuki, L. A., \& Alexander, C. M. (2010). Handbook of multicultural counseling (3rd ed.). Thousand Oaks, CA: Sage Publications.

Ponticelli, C. (1999). Crafting Stories of Sexual Identity Reconstruction. Social Science Quarterly, 62(2), 157-172.

Popper, K. R. (1934/1959). The logic of scientific inquiry. New York: Basic Books. 
Preissle, J. (2013). Qualitative futures: Where we might go from here. In N. K. Denzin \& Y. S. Lincoln (Eds.), The landscape of qualitative research (4th ed., pp. 517-543). Thousand Oaks, CA: Sage Publications.

Rennie, D. L., Watson, K. D., \& Monteiro, A. M. (2002). The rise of qualitative research in psychology. Canadian Psychology, 43, 179-189.

Rogers, C. R. (1951). Client-centered therapy. Boston: Houghton Mifflin.

Saini, M., \& Shlonsky, A. (2012). Systematic synthesis of qualitative research. New York: Oxford University Press.

Sandstrom, K. L., Martin, D. D., \& Fine, G. A. (2006). Symbols, selves, and social reality: A symbolic interactionist approach (2nd ed.). Los Angeles, CA: Roxbury Publishing.

Schwandt, T. A. (1996). Farewell to criteriology. Qualitative Inquiry, 2(1), 58-72.

Schwandt, T. A. (2001). Dictionary of qualitative inquiry. Thousand Oaks, CA: Sage Publications.

Smart, C. (2009). Shifting horizons: Reflections on qualitative methods. Feminist theory, 10(3), 295-308.

Smith, D. W. (2011). Phenomenology. The Stanford encyclopedia of philosophy (E. N. Zalta, Ed.). Retrieved from http://plato. stanford.edu/archives/fall2011/entries/phenomenology

Snow, D. A., \& Anderson, L. (1987). Identity work among the homeless: The verbal construction and avowal of personal identities. The American Journal of Sociology, 92(6), 1336-1371.

Strauss, A., \& Corbin, J. (1998). Basics of qualitative research: Techniques and procedures for developing grounded theory (2nd ed.). Thousand Oaks, CA: Sage Publications.

Stryker, S. (1987). The vitalization of symbolic interactionism. Social Psychology Quarterly, 50, 83-94.

Torrance, H. (2008). Building confidence in qualitative research: Engaging the demands of policy. Qualitative Inquiry, 14(4), 507-527.

Tracy, S. J. (2010). Qualitative quality: Eight “big-tent” criteria for excellent qualitative research. Qualitative inquiry, 16(10), $837-851$.

Wertz, F. J. (2011). A phenomenological psychological approach to trauma and resilience. In F. J. Wertz, L. M. McMullen, R. Josselson, R. Anderson, \& E. McSpadden (Eds.), Five ways of doing qualitative analysis: Phenomenological psychology, grounded theory, discourse analysis, narrative research, and intuitive inquiry (pp. 124-164). New York: Guilford Press.

Wertz, F. J., Charmaz, K., McMullen, L. J., Josselson, R., Anderson, R., \& McSpadden, E. (2011). Five Ways of Doing Qualitative Analysis: Phenomenological Psychology. Grounded Theory, Discourse Analysis, Narrative Research, and Intuitive Inquiry. New York: Guilford Press. 